\title{
The Relationship between Murottal Therapy and Pain Quality in College
}

\section{Students with Musculoskeletal Pain in 2019}

\author{
Thyra Annisaa ${ }^{1}$, Riezky Valentina $^{2}$, Aulia Chairani ${ }^{3}$

 \\ ${ }^{2}$ Department of Neurology, Fakultas Kedokteran Universitas Pembangunan Nasional "Veteran”, Jakarta \\ ${ }^{3}$ Department of Public Health, Fakultas Kedokteran Universitas Pembangunan Nasional "Veteran”, Jakarta
}

\begin{abstract}
Musculoskeletal pain is often called as musculoskeletal disorder (MSDs). One of the most common causes of musculoskeletal pain is occupational-related causes. Musculoskeletal pain is often experienced by college students. The factors that influence the occurrence of musculoskeletal pain in college students are learning activities as well as static body positions/posture while studying. This causes discomfort in learning activities on college students. This study aims to determine the relationship/correlation between the administration of murottal therapy and the quality of musculoskeletal pain in 2016 class Medical Faculty students of UPN (FK UPN). This research type is semi-experimental using a cohort study design. The sampling technique uses purposive sampling. The research sample used was 68 people. The data was collected at the Medical Faculty of UPN 'Veteran' Jakarta using a research instrument in the form of a Nordic Musculoskeletal Questionnaire (NMQ) and measured by the Numeric Rating Scale (NRS) pain scale. The results indicated that 30 students (44.1\%) had mild pain, 37 (55.4\%) had moderate pain, 1 (1.5\%) had severe pain respectively before murottal therapy is given. The results of bivariate analysis using the Wilcoxon test indicated that there was a relationship between murottal therapy and the quality of musculoskeletal pain in 2016 class Medical Faculty students of UPN $(p=0.000)$. The easy and inexpensive therapy of pain management is necessary such as through the administration of murottal therapy for 15 minutes.
\end{abstract}

Keywords: Musculoskeletal Disorders, Pain, Murottal Therapy

\section{ABSTRAK}

Nyeri muskuloskeletal sering disebut gangguan muskuloskeletal.Salah satu penyebab terseringnya nyeri muskuloskeletal adalah karena pekerjaan. Nyeri muskuloskeletal seringkali dialami oleh mahasiswa. Faktor-faktor yang berpengaruh pada kejadian nyeri muskuloskeletal pada mahasiswa adalah kegiatan belajar mengajar serta posisi tubuh statis saat belajar. Hal ini menyebabkan ketidaknyamanan dalam kegiatan belajar mengajar pada mahasiswa.Penelitian ini bertujuan untuk mengetahui hubungan antara pemberian terapi murottal dengan kualitas nyeri muskuloskeletal pada mahasiswa FK UPN angkatan 2016.Jenis penelitian ini semi-eksperimetal dengan desain penelitian kohort.Teknik pengambilan sampel menggunakan purposive sampling. Sampel penelitian yang digunakan sebanyak 68 orang. Pengambilan data dilakukan di Fakultas Kedokteran UPN 'Veteran' Jakarta menggunakan instrumen penelitian berupa kuesioner Nordic Musculoskeletal Questionnaire (NMQ) dandiukur dengan skala nyeri Numeric Rating Scale (NRS). Hasil penelitian menunjukkan mahasiswa dengan nyeri ringan sebanyak 30 orang (44,1\%), 37 orang nyeri sedang (55,4), 1 orang mengalami nyeri berat $(1,5 \%)$ sebelum diberikan terapi murottal. Hasil analisis bivariat dengan uji Wilcoxon menunjukkan terdapat hubungan antara terapi murottal dengan kualitas nyeri muskuloskeletal pada mahasiswa FK UPN angkatan 2016 ( $p=0,000)$. Manajemen penanganan nyeri dengan terapi yang mudah dan murah diperlukan seperti pemberian terapi murottal selama 15 menit.

Kata Kunci: Gangguan Muskuloskeletal, Nyeri, Terapi Murottal 


\section{INTRODUCTION}

Musculoskeletal disorders such as in the neck and lower back have been reported to be significant health issues in industrialized countries. ${ }^{[1]}$ Many of pain incidence due to musculoskeletal disorders in Italy study, occurred at the age of 20-75 years. $^{[2]}$ Occupational musculoskeletal disorders are one of the biggest issue in the modern environment. [3] Musculoskeletal disorders is a terminology to describe the damage or pain in muscles, nerves, ligaments, joints, tendons, and other structures that support the body, neck and back. ${ }^{[1]}$ The causes of musculoskeletal disorders mainly consist of 3 factors, they are style, repetitive activity, and unnatural work posture/behaviour. ${ }^{[4]}$ Statistically, in Health Issue Profile in Indonesia in 2013, it was indicated that around $40.5 \%$ of illnesses suffered by workers were closely related to their works, while musculoskeletal disorders were ranked first with $16 \%{ }^{[3]}$ In college students, sitting during learning with a static posture in a chair for hours could cause complaints for musculoskeletal pain. The most common locations of musculo-skeletal complaints based on measurement of Nordic Body Map, are on the neck, buttocks, waist, and shoulders. ${ }^{[5]}$ According to a study on the prevalence and factors associated with the pain in the neck, shoulder and lower back in 232 medical students at Malaysian Medical College, it was found that $62.9 \%$ of participants suffered from musculoskeletal pain in the neck, followed by lower back pain. ${ }^{[6]}$ Then the pain quality measurement in the pain due to musculoskeletal disorders was conducted using Numeric Rating Scale (NRS), it's a unidimensional measurement for pain intensity in adults that is valid and reliable, this method is also chosen due to its completeness and easiness. ${ }^{[7]}$ Precise or proper pain management is a management that covers all aspects of pain, such as physical as well as psycho-cognitive. ${ }^{[8]}$ Pharmacological therapy is chosen more often because the effect is faster. However, that does not mean that nonpharmacological therapy is not chosen at all. One of non-pharmacological therapy chosen to deal with the pain is audio therapy. Audio therapy is a therapy using distraction method, usually in the form of music therapy or murottal therapy. ${ }^{[9]}$

Murottal is a distraction technique used in pain management. ${ }^{[10]}$ According to Islamic Medicine for Education and Research in Florida, United States, it was found that listening to the readings of the verses of Qur'an can reduce nervous tension and it has been proven by computerized quantitative and qualitative measurements. ${ }^{[10]}$ The results indicated that $97 \%$ of those who listened to the verses of the Qur'an experienced/felt calmness. ${ }^{[11]}$ One of the chapters (surah) which has a teurapetic effect is chapter (Surah) Ar-Rahman. The recitation of Surah Ar-Rahman can reduce stress hormones and activate natural endorphin hormones that could avoid anxiety and increase relaxation effects in the research carried out/administered on mothers who will give birth. ${ }^{[12]}$ The learning activities on college students certainly affect to the occurrence of pain risk due to musculoskeletal disorders. In a study, it was said that the level of pain experienced by post-operative (post-surgical) patients was decreased after a murottal have been played out for 15 minutes, and it was also said to have caused a relaxed and comfortable for the respondents. ${ }^{[13]}$

\section{METHOD}

\section{Desain Penelitian Research Design}

The type of research is a quasiexperimental study with the objective of finding the relationship between variables using cohort prospective approach by recording the patient's medical record results with data collection using longitudinal time approach. ${ }^{[14]}$ 


\section{Population and Sample}

In this study, the population to be studied was the 2016 class (year) college students of Medical Faculty of UPN 'Veteran' Jakarta. The selected sample was the 3rd level (semester) college students of Medical Faculty of UPN 'Veteran' Jakarta who had complaints of musculoskeletal pain in the neck, shoulder and lower back area. Respondents sampled are respondents who meet the inclusion criteria in the form of Moslem, do not experience pain due to musculoskeletal disorders caused by an illness, infection, trauma to the bone or muscle, post-surgical conditions and are acute (less than 3 months).

\section{Sampling}

This study used a sampling that included 113 Moslem UPN Medical Faculty (FK UPN) college students who were then selected by filling in the Nordic Musculoskeletal Questionnaire Specific area that includes pain in the shoulder, lower back and neck. It was obtained 68 respondents who met the inclusion and exclusion criteria using the Purposive Sampling technique.

\section{Data Collection}

Data sources are primary data collected directly using the questionnaire of Nordic Musculoskeletal Questionnaire Specific area and also using the Numeric Rating Scale (NRS) to measure the quality of pain before and after murottal therapy interventions/administration.

\section{Research Procedure}

The researchers took the sample by diagnosing the sample population using the Nordic Musculoskeletal Questionnaire (NMQ), the sample population was then given a therapeutic intervention for 15 minutes, and using the Numeric Rating Scale (NRS) pain scale to measure the pain quality.

\section{RESULT AND DISCUSSION}

\section{Univariate Analysis Results}

Respondents Characteristics

The characteristics of study sample only included the gender. The respondents' distribution according to these characteristics can be seen in table 1 . The data indicates that the gender characteristics study sample were 13 males $(19.1 \%)$ and 55 females $(80.8 \%)$. Based on the gender of the respondents in this study, the most gender of the study were 55 female respondents. According to a certain study, in general, male and female have no significant difference in responding to pain, because there are no anatomically specific differences that will affect to this. ${ }^{[2]}$ However, this is not in line with other studies which indicate that male experience a higher intensity of pain compared to female on the grounds that male are hard workers, thus the intensity of pain will be different. ${ }^{[15]}$ Based on the most common location of musculoskeletal pain, 27 respondents experienced pain in the neck area $(39.7 \%)$. This is consistent with the results of study of medical students at Malaysian Medical College, whereby $62.9 \%$ of participants suffered from musculoskeletal pain in the neck, followed by lower back pain. ${ }^{[2]}$ The above data is also in line with other studies, based on the most common occurrence location of the musculoskeletal complaints, it was found that they are respectively, neck, buttocks, waist, and shoulders. This is because the college students spent their learning activities by sitting on a chair for hours with a static posture, which could induce musculoskeletal pain complaints. ${ }^{[5]}$ 
Table 1. Distribution of respondents by gender, location of musculoskeletal Pain and median in the FK (Medical Faculty) of UPN "Veteran" Jakarta

\begin{tabular}{lcc}
\hline \multicolumn{1}{c}{ Variable } & N & \% \\
\hline Gender & 13 & 19.1 \\
$\quad$ Male & 55 & 80.8 \\
$\quad$ Female & & \\
Location of Musculoskeletal Pain & 25 & 36.7 \\
$\quad$ Shoulder & 27 & 39.7 \\
$\quad$ Neck & 16 & 23.5 \\
$\quad$ Lower back & & \\
$\quad$ NRS score & 4 & \\
Before (Prior to) Murottal & $1-7$ & \\
Median & & \\
Minimum - Maximum & & \\
After Murottal & 1 & \\
Median & $0-5$ & \\
Minimum-Maximum 0-5 & & \\
\hline
\end{tabular}

Source: Primary Data, 2019

Meanwhile, the median NRS score in college students suffering from musculoskeletal pain before being administration of murottal was 4 , and the median NRS score after administration of murottal was 1 . The minimum NRS score was 1 , with maximum score was 7 before being given murottal therapy. After murottal therapy is given, the minimum NRS score was 0, while the maximum score was 5.

\section{Bivariate Analysis Results}

Relationship/Correlation of Pain Levels Before and After Administration of Murottal Therapy

Table 2 indicates the results of bivariate analysis using Wilcoxon alternative testing, showing the results of $p$ $=0.0001$, therefore there is a relationship between musculoskeletal pain score in respondents before murottal administration and after murottal administration. Bivariate testing in the respondent group using the Wilcoxon correlation test between the Numeric Rating Scale (NRS) score before and after administration of murottal therapy for 15 minutes obtained $\mathrm{P}$ value $=0.0001$. This result indicates that $p$ $<0.05$, thus $\mathrm{H} 1$ was accepted and $\mathrm{H} 0$ was rejected, showing a relationship or correlation between murottal therapy with the quality of musculoskeletal pain in the Medical Faculty students of UPN 'Veteran' Jakarta.

This proves the findings in the research $^{[16]}$, that murottal therapy of recitation of quran's short surah/chapter in juz 30 which are more common in people's hearing using tape recorder and earphones which is played for 15 minutes, it was found that listening to quran murottal is also a form of audio distraction in reducing pain quality.

Table 2. Relationship of pain levels before and after administration of murottal therapy.

\begin{tabular}{|c|c|c|c|c|c|c|c|c|c|c|c|c|}
\hline \multirow[t]{2}{*}{ Category } & \multicolumn{2}{|c|}{ No Pain } & \multicolumn{2}{|c|}{$\begin{array}{l}\text { Mild } \\
\text { Pain }\end{array}$} & \multicolumn{2}{|c|}{$\begin{array}{c}\text { Moderate } \\
\text { Pain }\end{array}$} & \multicolumn{2}{|c|}{$\begin{array}{c}\text { Severe } \\
\text { Pain }\end{array}$} & \multicolumn{2}{|c|}{ Total } & \multirow[b]{2}{*}{ P Value } & \\
\hline & $\mathrm{N}$ & $\%$ & $\mathrm{~N}$ & $\%$ & $\mathrm{~N}$ & $\%$ & $\mathrm{~N}$ & $\%$ & $\mathrm{~N}$ & $\%$ & & \\
\hline Before & 0 & 0 & 30 & 44.1 & 37 & 55.4 & 1 & 1.5 & 68 & 100 & & 0.000 \\
\hline After & 22 & 32.4 & 40 & 58.8 & 6 & 8.8 & 0 & 0 & 68 & 100 & & 0.000 \\
\hline
\end{tabular}


Table 3. Comparison of NRS scores after administration of murottal

\begin{tabular}{lc}
\hline $\begin{array}{l}\text { NRS Score (Before and } \\
\text { After) }\end{array}$ & N \\
\hline Decreased & 46 \\
Sedentary/unchanged & 21 \\
Increased & 1 \\
Total & 68 \\
\hline
\end{tabular}

\section{Comparison of NRS Scores After} Administration of Murottal

Based on Table 3, it was found that NRS scores of 46 people were decreased after being given murottal therapy, while 21 people were remained unchanged after being given murottal therapy, and NRS score of 1 person was found to increase after being given murottal therapy.

According to the results in table 3, there were several changes such as a decrease in the level of no pain to 22 people, a decrease to mild pain from 40 to 22 people, a decrease to moderate pain from 37 to 6 people, and an increase occurred in 1 person to moderate pain level.

Based on one study results, it was concluded that the administration of qur'an murrotal therapy can increase the respondents' sense of relaxation and calm so that it can affect the perception, emotions of the respondents which resulting on the ability of a cognitive adaptation that is able to control the pain to certain tolerable limit. ${ }^{[13]}$ Therefore, in accordance with the results of the study whereby respondents tend to experience a decrease in the level of pain quality to a lower level. Not all respondents felt/experienced the same level of pain. 22 respondents did not experience any changes in pain levels, while 1 respondent experienced an increase.

According to one study, everyone has a way to respond to their pain, because the threshold/limit for pain stimulation is different and subjective for each individual. ${ }^{[10]}$ In this situation, the endocrine system, such as the adrenal glands secrete epinephrine hormone. An increase in the adrenaline and noradrenaline or epinephrine and norepinephrine hormones caused biochemical disregulation of the body, so that physical tension arises in the respondent. This condition could cause further anxiety and tension so as to form a feedback cycle that can increase overall emotional intensity and ultimately pain increase painfully.

In other study, the research subjects were maternity mothers, whereby during maternal conditions the respondents also experienced increased pain due to anxiety factors that cause physical tension and lead to increased pain intensity. ${ }^{[17]}$ Another factor that affects the pain is concentration. Concentration is also influenced by one's physical or biological condition which influences his or her psychological condition. ${ }^{[17]}$

\section{CONCLUSION}

Based on the analysis and discussion on the results of the study, it can be concluded that there is a significant relationship/correlation between the administration of murottal therapy and the quality of musculoskeletal pain in the Medical Faculty college students of UPN "Veteran" Jakarta. The highest/most level of pain before murottal therapy is given is moderate pain level of $55.4 \%$. The highest/most level of pain after murottal therapy is given is moderate pain level of $58.8 \%$. Finally, for the prevalence of 2016 class/year Medical Faculty college students of UPN "Veteran" Jakarta was $60.17 \%$.

\section{REFERENCES}

[1] American Academy of Orthopedic Surgeons (AAOS) 2015, Orthopedic hip Replacement, di akses tanggal 15 Januari 2019 http://orthoinfo.aaos.org/PDFs/A0037 7. pdf 
[2] Cimmino, MA, Parodi, M, Montecucco, C, Capotali, R 2011, 'The Correct Prednisone Starting Dose In Polymyalgia Rheumatica Is Related To Body Weight But Not To Disease Severity', BMC Musculoskeletal Disorders, di akses tanggal 3 Maret 2019

https://bmcmusculoskeletdisord.biome dcentral.com

[3] Shirazaei, M 2015, 'Evaluation Of Ergonomic Factors And Postures That Cause Muscle Pains In Dentistry Student's Bodies', Journal of Clinical an Experimental Dentistry, vol.7, no.3, di akses tanggal 7 Maret 2019 https://www.ncbi.nlm.nih.gov/pmc/art icles/PMC4554244/pdf/jced-7e414.pdf

[4] Occupational Health and Safety Council of Ontario (OHSCO) 2006, Resorce Manual for The MSD Prevention Guideline for Ontario, Ontario, Kanada.

[5] Zar, A 2012, Faktor-Faktor Yang Berhubungan Dengan Keluhan Muskuloskeletal Pada Upper Limb Extremities Mahasiswa Ketika Proses Belajar Mengajar Di Kelas Di Fakultas Kedokteran Dan Ilmu Kesehatan Universitas Islam Negeri Syarif Hidayatullah Jakarta Tahun 2012, Skripsi Fakultas Kesehatan Masyarakat Program Studi Sarjana Kesehatan Masyarakat. Fakultas Kedokteran dan Ilmu Kesehatan Universitas Islam Negeri Syarif Hidayatullah, Jakarta, di aksestanggal 28 Januari 2018

[6] Alshagga, MA, Nimer, AR, Yan, LP, Ibrahim, IAA, Al-Ghamdi, SS, AlDubai, SAR 2013, 'Prevalence and Factors Associated With Neck, Shoulder and Low Back Pains Among Medical Students in a Malaysian Medical College', BMC Research Notes, vol.6, no.1, di akses tanggal 3 Maret 2019
[7] Hawker, GA 2011, 'Measures of adult pain: Visual Analog Scale for Pain (VAS Pain), Numeric Rating Scale for Pain (NRS Pain), McGill Pain Questionnaire (MPQ), Short-Form McGill Pain Questionnaire (SF-MPQ), Chronic Pain Grade Scale (CPGS), Short Form-36 Bodily Pain Scale (SF-36 BPS), and Measure of Intermittent and Constant Osteoarthritis Pain (ICOAP)', American College of Rheumatology, vol.63, no.s11, November 2011, hlm. S240-s250, diakses pada 4 Maret 2019 https://doi.org/10.1002/acr.20543

[8] King, S 2011, 'The Epidemiology Of Chronic Pain In Children And Adolescents Revisited: A Systematic Review', PAIN, vol.152, no.12, Desember 2011, hlm. 2683-2684, diakses pada 5 Maret 2019

https://doi.org/10.1016/j.pain.2011.07. $\underline{016}$

[9] Nissa, QC, Nuraeni, N, Handayani, H 2018, 'The Effect Of Murattal To Relieve Dysmenorrhea Pain In Female Students', Journal of Maternity Health and Reproductive Health, vol.1, no.1, diakses pada 1 April 2019 http://mcrhjournal.or.id/index.php/jmc rh/article/view/3/11

[10]Handayani, R, Fajarsari D, Asih, DRT, Rohmah, DN 2014, 'Pegaruh Terapi Murottal Al-Qur'an Terhadap Penurunan Intensitas Nyeri Persalinan Dan Kecemasan Dalam Persalinan Primigravida Kala 1 Fase Aktif Di Rsud Prof. Dr Margono Soekardjo Tahun 2014', Jurnal Ilmiah Kebidanan, vol.7, no.1, Juni 2016, hlm. 119-129, diakses pada 1 Maret 2019

ojs.akbidylpp.ac.id/index.php/Prada/ar ticle/download/147/135

[11] Suprapti, Wirawati, MK 2016, 'Upaya Penurunan Intensitas Nyeri Persalinan Kala 1 Fase Aktif Dengan Murottal Al-Qur'an Di Rumah Sakit Umum Daerah Kota Semarang', Jurnal 
Asuhan Keperawatan, vol.2, no.1, di akses tangal 27 Maret 2019

http://jurnal.akper-

whs.ac.id/index.php/mak/article/view/ $18 / 31$

[12] Mahjoob, M 2016, 'The Effect of Holy Quran Voice on Mental Health', Journal of Religion and Health, vol.55, no.1, hlm. 38-42, diakses pada 26 Februari 2019

https://doi.org/10.1007/s10943-0149821-7

[13] Rochmawati, NP 2018, Pengaruh Murottal Qur'an Terhadap Nyeri Post Operasi Di Paviliun Asoka Rsud Kab. Jombang, Skripsi Sekolah Tinggi Ilmu Kesehatan Insan Cendekia Medika Jombang, di akses tanggal 3 Maret 2019

http://repo.stikesicme-

jbg.ac.id/592/2/143210033\%20SKRIP SI\%20NANIK\%20PUJI\%20ROCHM AWATI.pdf

[14] Notoatmodjo, S 2012, Metodologi Penelitian Kesehatan, Rineka Cipta, Jakarta.

[15] Yuan-Yi,C, Lok-Hi, C, Chun-Chieh, H, Liu, K, Luo-Ping, G, Pei-Ning, W 2012, 'Gender And Pain Upon Movement Are Associated With The Requirements For Postoperative Patient-Controlled IV Analgesia: A Prospective Survey Of 2,298 Chinese Patients', Canadian Journal of Anasthesia, vol.49, no.1, hlm.249-255 di akses tanggal 27 Maret 2019 http://www.ncbi.nlm.nih.gov/pubmed/ 11861342

[16] Cooke, M, Chaboyer, W, Hiratos, MA 2005,'Music And Its Effect On Anxiety In Short Waiting Periods: A Critical Appraisal', Jurnal of Clinical Nursing, vol.14, no.2, hlm. 145-155, di akses tanggal 18 Maret 2019

https://doi.org/10.1111/j.13652702.2004.01033.x

[17] Ilmiasih, R 2017, 'Pengaruh Teknik Hypnobirthing Terhadap Tingkat Kecemasan Ibu Hamil Pada Masa Persiapan Persalinan', di akses tanggal $\underline{8}$ Maret 2019researchreport.umm.ac.id/index.php/research report/article/download/1403/1617

[18] Bobaya, W, Kandou, GD, Rattu, AJM 2018, 'Hubungan Antara Status Gizi, Umur Dan Beban Kerja Fisik Dengan Keluhan Muskuloskeletal Pada Tenaga Kerja Bongkar Muat Di Pelabuhan Manado', Community Health, vol.3, no.1, di akses tanggal 12 Januari 2019

ejournalhealth.com/index.php/CH/arti cle/download/775/760

[19] Chunaeni, S, Lusiana, A, Handayani, E 2016, 'Efektifitas Terapi Murottal Terhadap Penurunan Nyeri Ibu Bersalin Kala I Fase Aktif', Jurnal Temu Ilmiah Hasil Penelitian dan Pengabdian Masyarakat, di akses tanggal 8 April 2019

https://jurnal.unimus.ac.id/index.php/p $\underline{\text { sn12012010/article/download/2113/21 }}$ $\underline{40}$

[20] Grimes, P, Legg, S 2004, 'Musculoskeletal Disorders (MSD) in School Students as a Risk Factor for Adult MSD: A Review of the Multiple Factors Affecting Posture, Comfort and Health in Classroom Environments', Journal of the Human-Environmental System, vol.7, no.1, di akses pada 5 April 2019 https://www.jstage.jst.go.jp/article/jhe s/7/1/7 $11 /$ pdf/-char/ja

[21] Prasetyo, SN 2010, Konsep Dan Proses Keperawatan Nyeri, Graha Ilmu, Yogyakarta. 